\title{
Breastfeeding profile and practice of Nigerian mothers: a cross-sectional survey
}

\author{
Chidozie Emmanuel Mbada ${ }^{1}$, Adekemi Eunice Olowokere ${ }^{2}$, Joel Olayiwola Faronbi ${ }^{2}$, \\ Funmilola Adenike Faremi ${ }^{2}$, Monisola Omoyeni Oginni ${ }^{2}$, Folasade Christianah Oyinlola- \\ Aromolaran $^{1}$, Emmanuel Abiodun Odeyemi ${ }^{1}$, Oluwakemi Ajoke Augustine ${ }^{2}$
}

\author{
${ }^{1}$ Department of Medical Rehabilitation, College of Health Sciences, Obafemi Awolowo University, Ile-Ife, Nigeria \\ ${ }^{2}$ Department of Nursing Sciences, Obafemi Awolowo University, Ile-Ife, Nigeria
}

Received: 9 September 2014

Accepted: 19 September 2014

\author{
*Correspondence: \\ Dr. Chidozie Emmanuel Mbada, \\ E-mail: doziembada@yahoo.com
}

Copyright: (c) the author(s), publisher and licensee Medip Academy. This is an open-access article distributed under the terms of the Creative Commons Attribution Non-Commercial License, which permits unrestricted non-commercial use, distribution, and reproduction in any medium, provided the original work is properly cited.

\begin{abstract}
Background: Breastfeeding patterns in the developing world are still below the recommended levels and the potential to improve child survival remains untapped. This study investigated the breastfeeding profile and practices of Nigerian nursing mothers.

Methods: This cross-sectional survey involved women at attending selected baby-friendly facilities in Ile-Ife, SouthWest, Nigeria who had breastfed their most recent baby for a minimum of six months. A self-administered questionnaire was used to obtain data on demographics, infant-maternal characteristics and breastfeeding practices. 383 mothers volunteered for this study, yielding a response rate of $95.7 \%$. Data were analyzed using descriptive and inferential statistics at 0.05 alpha level.

Results: The mean age of the respondent was $29.0 \pm 4.96$ years. Exclusive breastfeeding (EBF) rate was $86.2 \%$. Breastfeeding initiation time of less than 1 hour after delivery and 24 hours rooming-in practice rate was $78.3 \%$ and $79.1 \%$ respectively. Daily breastfeeding time and total breastfeeding duration was $8.06 \pm 2.33$ hours and $18.3 \pm 4.82$ months respectively. The mean onset time for water supplementation was $4.74 \pm 1.77$ months with a rate of $30.3 \%$ within 1-3 months. Weaning initiation time was mostly (43.9\%) within 12 to 18 month of infant's age. There was significant association between EBF practice and each of maternal education $\left(\mathrm{X}^{2}=6.554 ; \mathrm{P}=0.038\right)$ and SocioEconomic Status (SES) $\left(\mathrm{X}^{2}=19.32 ; \mathrm{P}=0.031\right)$ with most of the respondents in the lower SES $(56.1 \%)$ subscribing to EBF.

Conclusions: Exclusive breastfeeding (EBF) rate for the first six months among Nigerian mothers attending babyfriendly clinics was high. Breastfeeding initiation time after delivery was early, water supplementation to breastfeeding was before 5 months of the infant's life and weaning practice was late. Maternal educational level and socio-economic status significantly influenced EBF practice.
\end{abstract}

Keywords: Exclusive breastfeeding, Baby-friendly, Practice, Nigeria

\section{INTRODUCTION}

Breastfeeding is the act of breast milk transference from the mother to the infant. ${ }^{1}$ Breastfeeding satisfies baby's emotional needs and it increases bonding between mother and infant ${ }^{2}$ and it is considered to be physiologically, biochemically, psychologically and immunologically important. ${ }^{3}$ Consequently, several coordinated activities and policies to promote health among women, new-borns and infants through breastfeeding have been actively advocated for and promoted. Based on empirical evidences on the benefits of breastfeeding to the mother 
and child, the World Health Organization (WHO) ${ }^{4}$ has recommended 2 year breastfeeding; first 6 months Exclusive breastfeeding (EBF); and more than 8 times breastfeeding of the baby per day in the first 3 months of an infant's life. The WHO and the United Nations Children's Fund (UNICEF) in 1991 launched a global effort to implement practices that protect, promote and support breastfeeding through the baby-friendly hospital initiative. The initiative is reported to have provided optimal support for breastfeeding by increasing the likelihood of babies being exclusively breastfed for the first six months. ${ }^{1}$

The WHO and UNICEF baby friendly hospital initiative recommends infants should be exclusively breastfed for the first six months of life to achieve optimal health and development, followed by complementary foods while continuing breastfeeding for up to two years or beyond. ${ }^{5}$ Even though there are global recommendations regarding the best practises of breastfeeding, the rate of adherence to breastfeeding is reported to be declining worldwide. ${ }^{6,7}$ Singh $^{3}$ submitted that there has been a general decrease in the practice of breastfeeding both in terms of prevalence and duration in the past few decades and recommended a need to promote, protect and support breastfeeding as a child survival strategy. Breastfeeding rates vary in different countries and from one geographic region to another. $^{8,9}$ It has been observed that breastfeeding patterns have improved significantly in some countries over the recent decade. ${ }^{10,11}$ Conversely, breastfeeding patterns are still below the recommended levels in the developing world as a whole and the potential to improve child survival remains untapped. ${ }^{12-15}$ Furthermore, data on breastfeeding practices are still inadequate in the developing countries. Therefore, this study assessed breastfeeding profile and practices of nursing mothers attending selected baby-friendly facilities in Ile-Ife, South-West, Nigeria.

\section{METHODS}

This cross-sectional survey involved women who had breastfed their most recent baby for a minimum of six months and were attending post-natal clinics from five government-owned baby-friendly facilities (namely Ife hospital unit of the Obafemi Awolowo University Teaching Hospital Complex (OAUTHC), Eleyele Urban comprehensive health center of the OAUTHC, Enuwa primary health center, comprehensive health center Aderemi and Okeitubu comprehensive health center Modakeke) in Ife central and Ife east local government, areas of Osun state, South West, Nigeria respectively.

Ile-Ife is an ancient settlement of the Yoruba tribe in Osun State in the South-western part of Nigeria.

Ethical approval for the study was sought from the ethics and research committee of the OAUTHC. All the respondents gave signed informed consent prior to participation.
The questionnaire for the study was developed from previous studies and expert review. Test-retest reliability of the English version of the questionnaire yielded a correlation coefficient of $\mathrm{r}=0.967$ at $\mathrm{P}=0.001$.

The items of the Yoruba language (the local language among the respondents) version of the questionnaire yielded agreements percentage that ranged from 94 to $100 \%$, and the corresponding kappas ranged from 0.76 to 1.00 .

The self-administered questionnaires were distributed to breastfeeding mothers attending medical appointments at the aforementioned facilities. Data were collected on demographics, infant-maternal characteristics and breastfeeding practices.

\section{Data analyses}

Data were summarized using descriptive (mean, standard deviation, and frequency) and inferential statistics of Chisquare test of association. The level of significance was set at $\mathrm{P}<0.05$. Data were analyzed with Statistical Package for Social Sciences (SPSS) software (version 16).

\section{RESULTS}

A total of 400 questionnaires were distributed, however, 383 were returned yielding a responsive rate of $95.7 \%$. The mean age of the respondent was $29.0 \pm 4.96$ years.

Table 1 shows the socio-demographic, maternal and infant characteristics. From the result, $68.1 \%$ of the respondents were multiparous and $86.7 \%$ had vagina delivery.

Table 2 shows the breastfeeding profile and practices of the respondents. $78.3 \%$ of the respondents had less than $1 \mathrm{hr}$ breastfeeding onset time after delivery and $79.1 \%$ reported 24 hours rooming-in practices. $86.2 \%$ of the respondents practiced EBF.

The daily breastfeeding time and total breastfeeding duration of the respondents was $8.06 \pm 2.33$ hours and $18.3 \pm 4.82$ months respectively.

Weaning was reported as early as less than 6 months of the infant life by $8 \%$ of the respondents while majority $(43.9 \%)$ weaned their children within 12 to 18 months.

The mean time for the onset of water administration as complementary to breastfeeding was $4.74 \pm 1.77$ months. $30.3 \%$ of the respondents administered water within 1-3 months, while $58.7 \%$ administered water after 6 months of the infant's age.

Of the respondents that practiced EBF, $22.5 \%$ practiced up to 12 months, $43.9 \%$ practiced up to 18 months, $32.9 \%$ up to 24 months. 
The Chi-square test of association between EBF and each of age, religion, education, occupation, and parity is presented in Table 3.

There was no significant association between EBF practice and each of age $(\mathrm{P}=0.367)$, occupation $(\mathrm{P}=$ $0.426)$ and parity $(\mathrm{P}=0.599)$.

However, there was a significant association between education and $\mathrm{EBF}$ practice $\left(\mathrm{X}^{2}=6.554 ; \mathrm{P}=0.038\right)$.

Most of the respondents in the lower Socio-economic Status (SES) $(56.1 \%)$ practiced EBF while $40.0 \%$ and $3.9 \%$ of the respondents in the middle and lower socioeconomic strata respectively practiced EBF.

There was a significant association between SES and EBF practice $(\mathrm{X} 2=19.32 ; \mathrm{p}=0.031)$.

Table 1: Socio-demographic, maternal and infant characteristics.

\begin{tabular}{|lll|}
\hline Variable & \multicolumn{1}{l}{ \% } \\
\hline Age (in years) & & \\
\hline$\leq 30$ & 224 & 58.5 \\
\hline$>30$ & 159 & 41.5 \\
\hline Religion & & \\
\hline Christianity & 275 & 71.8 \\
\hline Islam & 108 & 28.2 \\
\hline Education & & \\
\hline Pry & 33 & 8.6 \\
\hline Secondary & 157 & 41.0 \\
\hline Tertiary & 193 & 50.4 \\
\hline Occupation & & \\
\hline Unemployed & 62 & 16.2 \\
\hline Private unskilled & 157 & 41.0 \\
\hline Private skilled & 76 & 19.8 \\
\hline Public junior & 62 & 16.2 \\
\hline Public senior & 26 & 6.8 \\
\hline Socioeconomic status & SES) \\
\hline Low SES & 220 & 57.4 \\
\hline Middle SES & 148 & 38.6 \\
\hline High SES & 15 & 3.9 \\
\hline Mode of delivery & & \\
\hline Vaginal & 332 & 86.7 \\
\hline Caesarean section & 51 & 13.3 \\
\hline Parity & & \\
\hline Primiparous & 122 & 31.9 \\
\hline Multiparous & 261 & 68.1 \\
\hline Infant gender & & \\
\hline Male & 187 & 48.8 \\
\hline Female & 196 & 51.2 \\
\hline Neonatal hospitalization \\
\hline Yes \\
\hline No & 43.6 \\
\hline
\end{tabular}

Table 2: Breastfeeding profile and practices of the respondents.

\begin{tabular}{|c|c|c|}
\hline Variable & n & $\%$ \\
\hline \multicolumn{3}{|c|}{ First breastfeeding initiation time } \\
\hline$\leq 1$ hour & 300 & 78.3 \\
\hline 1-3 hours & 55 & 14.4 \\
\hline 3-6 hours & 10 & 2.6 \\
\hline 6-12 hours & 7 & 1.8 \\
\hline 12-24 hours & 4 & 1.0 \\
\hline$>24$ hours & 7 & 1.9 \\
\hline Total & 383 & 100 \\
\hline \multicolumn{3}{|l|}{ Rooming-in practice } \\
\hline$\leq 12$ hours & 13 & 3.4 \\
\hline$>12$ less than 24 hours & 67 & 17.5 \\
\hline 24 hours & 303 & 79.1 \\
\hline Total & 383 & 100 \\
\hline \multicolumn{3}{|c|}{ Exclusive breastfeeding duration } \\
\hline Within 3 months & 19 & 4.9 \\
\hline 4-5 months & 34 & 8.9 \\
\hline 6 months & 330 & 86.2 \\
\hline \multicolumn{3}{|l|}{ Weaning practices } \\
\hline$<6$ months & 3 & 0.8 \\
\hline 6 to 12 months & 6 & 22.5 \\
\hline 12 to 18 months & 168 & 43.9 \\
\hline Up to 2 years & 126 & 32.9 \\
\hline Total & 383 & 100 \\
\hline \multicolumn{3}{|c|}{ Administration of water } \\
\hline $1-3$ months & 116 & 30.3 \\
\hline 4-6 months & 42 & 11.0 \\
\hline$>6$ months & 225 & 58.7 \\
\hline Total & 383 & 100 \\
\hline
\end{tabular}

Table 3: Association between exclusive breastfeeding practice and each of age, religion, education, occupation and parity.

\begin{tabular}{|c|c|c|c|c|}
\hline & \multicolumn{2}{|c|}{$\begin{array}{l}\text { Exclusive breastfeeding } \\
\text { practice }\end{array}$} & \multirow[b]{2}{*}{$\mathrm{X}^{2}$} & \multirow[b]{2}{*}{$P$ value } \\
\hline & Yes, n (\%) & No, n $(\%)$ & & \\
\hline \multicolumn{5}{|l|}{ Age (in years) } \\
\hline$\leq 30$ & $190(84.8)$ & $34(15.2)$ & \multirow{2}{*}{0.813} & \multirow{2}{*}{0.367} \\
\hline$>30$ & $140(88.1)$ & $19(11.9)$ & & \\
\hline \multicolumn{5}{|l|}{ Religion } \\
\hline Christianity & $239(86.9)$ & $36(13.1)$ & \multirow{2}{*}{0.457} & \multirow{2}{*}{0.499} \\
\hline Islam & $91(84.3)$ & $17(15.7)$ & & \\
\hline \multicolumn{5}{|l|}{ Education } \\
\hline Pry & $25(75.8)$ & $8(24.2)$ & \multirow{3}{*}{6.554} & \multirow{3}{*}{0.038} \\
\hline Secondary & $131(83.4)$ & $26(16.6)$ & & \\
\hline Tertiary & $174(90.2)$ & $19(9.8)$ & & \\
\hline \multicolumn{5}{|l|}{ Occupation } \\
\hline Unemployed & $57(85.1)$ & $5(7.5)$ & \multirow{5}{*}{3.856} & \multirow{5}{*}{0.426} \\
\hline Private unskilled & $132(84.1)$ & $25(15.9)$ & & \\
\hline Private skilled & $63(82.9)$ & $13(17.1)$ & & \\
\hline Public junior & $54(87.1)$ & $8(12.9)$ & & \\
\hline Public senior & $24(92.3)$ & $2(7.7)$ & & \\
\hline \multicolumn{5}{|l|}{ Parity } \\
\hline Primiparous & $103(84.4)$ & 19 (15.6) & \multirow{2}{*}{0.277} & \multirow{2}{*}{0.599} \\
\hline Multiparous & $217(86.5)$ & $34(13.5)$ & & \\
\hline
\end{tabular}




\section{DISCUSSION}

This study assessed breastfeeding profile and practices of nursing mothers attending from selected baby-friendly facilities in Ile-Ife, South-west, Nigeria. The maternal demographics showed that most of the women in this study were multiparous and had a vaginal delivery. Relatively, a smaller percentage (13.3\%) of the mothers had caesarean section. This could be associated with a widely held belief that women in the West African subregion have an aversion for surgical delivery. ${ }^{16}$ From the result of this study, majority of the mothers had less than one hour breastfeeding initiation time after delivery $(78.3 \%)$. Data on breastfeeding initiation time are sparse and differs across different countries. A study among Turkish mother reported an overall breastfeeding initiation of $32.8 \%$ and $72.8 \%$ within the first and hour two hours after delivery respectively. ${ }^{17}$ Madagascar mothers were reported to have a rate of $78 \%$ for breastfeeding initiation within the first hour ${ }^{18}$ however, a rate as low as $3.4 \%$ was reported among Nepalese mothers. ${ }^{19}$ Factors such socio-cultural beliefs, delay in lactogenesis, sub-optimal behaviour of new-borns to accept breastfeeding especially in those exposed to labour medication during delivery are frequently associated with the initiation of breastfeeding. ${ }^{17,20,21}$

Rooming-in practice was reported among $79.1 \%$ of the mothers in this study. Cotton and Garcia 22 reported a rooming-rate of $70 \%$ among Brazilian mothers. Rooming-in practice rate ranging from 25 to $98.5 \%$ has been reported among South Korean mother. ${ }^{23,24}$ Nurses' document information on EBF practices on electronic health record for rooming-in practice in 2010 was $81.38 \%{ }^{25}$ Rooming-in practice allows the mother and infant to remain together 24 hours a day. ${ }^{3}$ WHO and UNICEF included rooming practice in their joint statement to maternity units worldwide to protect, promote and support breastfeeding. ${ }^{26}$ Rooming-in allows for skin to skin contact and it promotes pre-feeding behavioural instinct in the infant to start sucking the breast by him/herself ${ }^{27,28}$ and lactogenesis; $;^{29,30}$ helps the mother to keep the baby warm $^{31}$ and enhances baby's relaxation ${ }^{32}$ and a non-crying state. ${ }^{33}$

Eighty six point two percent of the mothers in this study practiced EBF. The daily breastfeeding time of the mothers was $8.06 \pm 2.33$ hours while breastfeeding duration was $18.3 \pm 4.82$ months. Breastfeeding rates have been reported to vary in different countries and from one geographic region to another. ${ }^{8,9}$ The rates for EBF found in this study were higher than those reported in most studies from Western and Asian countries. A study by $\operatorname{Tan}^{34}$ among Malaysian women reported that $32.8 \%$ of the respondents exclusively breastfeed for six months while $14.5 \%$ practice mixed infant feeding. Another study by Khassawneh et al. ${ }^{9}$ among Jordanian women found a rate of over 58\% and $30 \%$ respectively for full were mixed breastfeeding practices. The breastfeeding rate in this study was higher than the $44.3 \%$ to $47.2 \%$ breastfeeding rate at 6 months and $23.8 \%$ to $25.5 \%$ breastfeeding rate at 12 months observed from 2008 to 2009 among women in the USA. However, breastfeeding rate observed in this study was lower than a report among Iranian women. ${ }^{35}$ Variation in rates of breastfeeding practices can be a reflection of differences in the sociodemographic and cultural inclination. ${ }^{9}$ The EBF rate obtained in this study is higher and contrasts a recent report by Agho et al. ${ }^{36}$ that the EBF rate in Nigeria is low and falls well short of the expected levels needed to achieve a substantial reduction in child mortality. The study by Agho et al. ${ }^{36}$ was an analysis of secondary data from publicly available datasets of the Nigeria demographic and health survey ${ }^{37}$ On the other hand, the samples in the present study comprised mothers attending baby-friendly clinics and who may have imbibed the baby-friendly initiatives and consequently the higher EBF rate observed in the study.

Breastfeeding weaning initiation time of less than 6 months of the infant life was reported by $0.8 \%$ of the mothers in this study. Traditionally, weaning is used to describe the process of withdrawal from breastfeeding with the gradual replacement of fresh or modified animal milk or by semisolid food. ${ }^{38}$ The rate of early weaning in this study is relatively small compared with reports from the Western countries. ${ }^{39-42}$ Early and rapid weaning and introduction of solid foods have negative impact on the infant's health and it is reported to increase susceptibility to skin infections ${ }^{43-46}$, enteritis, ${ }^{47}$ respiratory illnesses ${ }^{46}$ and childhood obesity. ${ }^{48}$ The time of initiation of weaning varied widely in this study. However, majority of the mothers $(99.2 \%)$ practiced late weaning with weaning initiation of $22.6 \%, 43.9 \%$ and $32.9 \%$ for 6 to 12 months, 12 to 18 months and up to 2 years duration respectively. These findings are consistent with report that a vast majority of mothers in sub-Saharan Africa breastfeed for long durations. ${ }^{49}$ The World Health Organization (WHO) recommended 6 months postpartum for the initiation of weaning. ${ }^{50}$ Conversely, there has been global debate on the optimal weaning age. 4, 6 months or a window between these two time points as been advocated as the optimal age for introducing solids to an infant's diet. ${ }^{51-53}$ Weaning practice is associated with cultural predisposition, ${ }^{54,55}$ socio-demographic and socioeconomic factors, ${ }^{55-57}$ wrong perception of insufficient of milk $^{58}$, maternal factors (such as ill-health, pregnancy or death) $)^{59-61}$ and psychosocial beliefs (e.g. erroneous belief of saggy breast with late weaning $)^{2,63}$ among others. However, poor feeding habit with consequent nutritional deficiency and failure to thrive have been linked with delay weaning of infant. ${ }^{64-66}$

The onset of water administration as complementary to breastfeeding in this study was approximately five months. $30.3 \%$ of the mothers administered water within 1-3 months, while 58.7\% administered water after 6 months of the infant's life. Water supplementation of infant's breastfeeding as early as the first month of birth is a prevalent practice among Africans and constitutes a major barrier to achieving greater level of compliance 
with exclusive breastfeeding. ${ }^{67,68}$ Eregie $^{67}$ in a study among Nigerian mothers reported that water supplementation accounted for $91.7 \%$ of partial breastfeeding up to one completed month. Another study among rural Nigerian women revealed that pre-lacteal feeding of water, herbal infusions and ritual fluids are the norm and breast milk is supplemented form birth, with water and teas. ${ }^{69}$ Water supplementation of breastfeeding is deeply engrained in Africa, as most infants are given water from birth, in part due to cultural perceptions that infants need water to survive. ${ }^{70}$ Similar to the finding of this study, Scariati et al. ${ }^{71}$ submitted that water supplementation of neonates was a prevalent practice among a cohort of US women.

This study showed that individual factors such as age, religion, occupation and parity status were not significantly associated with exclusive breastfeeding practice. The pattern of association between EBF practice and socio-demographic and maternal factors varies across studies. Some studies showed that mothers who were young in age, ${ }^{72,73}$ employed, ${ }^{74,75}$ less educated ${ }^{76}$ often do not practice EBF. However, there was a significant association between education and EBF practice in this study. Educational status has been reported as an important maternal factor associated with adopting exclusive breastfeeding practice. ${ }^{72,73,77}$

Furthermore, most of the respondents in the lower SES $(56.1 \%)$ practiced $\mathrm{EBF}$ while $40.0 \%$ and $3.9 \%$ of the respondents in the middle and lower socio-economic strata respectively practiced EBF. From previous studies, mothers in higher SES have been reported not to comply with exclusive breastfeeding practice. $^{72,77,78}$ Some researchers submitted that the inverse association between SES and EBF practice is due to greater affordability of foods other than breast milk by higher SES households, ${ }^{72,77,78}$ occupation and work status, ${ }^{72,79}$ and body image consciousness among mothers of highincome groups. ${ }^{80}$

\section{CONCLUSION}

Exclusive breastfeeding (EBF) rate among Nigerian mothers attending baby-friendly clinics was high. Breastfeeding initiation time after delivery was early, water supplementation to breastfeeding was before 5 months of the infant's life and weaning practice was late. Individual factors such as age, religion, occupation and parity status were not significantly associated with exclusive breastfeeding practice. Maternal educational level and socio-economic status significantly influenced EBF practice.

Funding: No funding sources

Conflict of interest: None declared

Ethical approval: The study was approved by the ethics research committee of the OAUTHC

\section{REFERENCES}

1. Chantry CJ, Eglash A, Labbok M, the Academy of Breastfeeding Medicine Board of Directors. ABM statements: position on breastfeeding. Breastfeed Med. 2008;3(4):267-70.

2. Uvnäs-Moberg K, Eriksson M. Breastfeeding: physiological, endocrine and behavioural adaptations caused by oxytocin and local neurogenic activity in the nipple and mammary gland. Acta Paediatr. 1996;85(5):525-30.

3. Singh B. Knowledge, attitude and practice of breast feeding: a case study. Eur J Sci Res. 2010;40(3):404-22.

4. World Health Organization (WHO). Global strategy for infant and young child feeding, 2003. Available at:

http://whqlibdoc.who.int/publications/2003/9241562 218.pdf. Accessed 12 September 2011.

5. World Health Organization (WHO). Indicators for assessing breast-feeding practices. In: WHO, eds. WHO Reference (WHO/CDD/SER/91.14). Geneva, Switzerland: World Health Organization; 1991:1-14.

6. Engebretsen IM, Wamani H, Karamagi C, Semiyaga $\mathrm{N}$, Tumwine J, Tylleskar $\mathrm{T}$. Low adherence to exclusive breastfeeding in Eastern Uganda: a community-based cross-sectional study comparing dietary recall since birth with 24-hour recall. BMC Paediatr. 2007;7:10.

7. UNICEF. UNICEF rings alarm bells as breastfeeding rates plummet in East Asia, 2012. Available at: http://www.unicef.org. Assessed 4 March 2013.

8. Vega López MG, González Pérez GJ. Maternal factors relating to breast-feeding duration in areas around Guadalajara, Mexico. Bull Pan Am Health Organ. 1993;27(4):350-9.

9. Khassawneh M, Khader Y, Amarin Z, Alkafajei A. Knowledge, attitude and practice of breastfeeding in the north of Jordan: a cross-sectional study. Int Breastfeed J. 2006;23(1):17.

10. Sguassero Y. Optimal duration of exclusive breastfeeding: RHL commentary. In: Sguassero Y, eds. The WHO Reproductive Health Library. Geneva: World Health Organization; 2008.

11. UNICEF. Overview of breastfeeding patterns, 2009. Available at: http://www.childinfo.org/breastfeeding_overview.ht ml. Accessed 12 August 2011.

12. UNICEF. Tracking progress on child and maternal nutrition: a survival and development priority, 2009. Available at: http://www.unicef.org. Assessed 11 June 2012.

13. Jones G, Steketee RW, Black RE, Bhutta ZA, Morris SS. Bellagio child survival study group: how many child deaths can prevent this year? Lancet. 2003;362:65-71.

14. MDGS. Nigeria millennium development goals report (NMDG), 2001. Available at: http://www.Mdgs.gov.ng. Accessed 04 March 2012. 
15. World Health Organization (WHO). Data bank on infant and young child feeding on Nigeria, 2010. http://www.who.int/nutrition/databases/infantfeeding /countries/nga.pdf. Accessed 24 November 2012.

16. Awoyinka BS, Ayinde OA, Omigbodun AO. Acceptability of caesarean delivery to antenatal patients in a tertiary health facility in south-west Nigeria. J Obstet Gynaecol. 2006;26(3):208-10.

17. Örün E, Yalçın SS, Madenda Y, Üstünyurt-Eras Z, Kutluk S, Yurdakök K. Factors associated with breastfeeding initiation time in a baby-friendly hospital. Turkish J Paediatr. 2010;52:10-6.

18. Baker EJ, Sanei LC, Franklin N. Early initiation of and exclusive breastfeeding in large-scale community-based programmes in Bolivia and Madagascar. J Health Popul Nutr. 2006;24(4):530-9.

19. Mullany LC, Katz J, Li YM, Khatry SK, LeClerg SC, Darmstadt GL, et al. Breast-feeding patterns, time to initiation, and mortality risk among newborns in Southern Nepal. J Nutr. 2008;138(3):599-603.

20. Amir LH, Donath S. A systematic review of maternal obesity and breastfeeding intention, initiation and duration. BMC Pregn Childbirth. 2007;7:9.

21. Chapman DJ, Perez-Escamilla R. Identification of risk factors for delayed onset of lactation. J Am Diet Assoc. 1999;99:450-4.

22. Cotton CW, Garcia Fragoso L. Rooming-in improves breastfeeding initiation rates in a community hospital in Puerto Rico. Bol Asoc Med P R. 2010;102(1):302.

23. Cho MJ, Cheon CM, Seo JK, Shin SM. A Survey on the factors of breast feeding failure related to the role of medical personnels. J Korean Pediatr Soc. 2001;44:389-96.

24. Yoo ML, Kang HS, Young MK, Jin SK, Ji YC, Hyun JS, et al. Complete rooming-in care of newborn infants. Korean J Paediatr. 2010;53(5):6348.

25. Smith PB, Moore K, Peters L. Implementing babyfriendly practices: strategies for success. Am J Matern/Child Nurs. 2012;37(4):228-33.

26. WHO/UNICEF. Protecting promoting, and supporting breastfeeding; the special role of maternal services. A joint WHO/UNICEF statement, 1993. Available whqlibdoc.who.int/publications/9241561300.pdf. Accessed 24 February 2012.

27. Bystrova K, Widströn A, Matthiesen A, RansjöArvidson A, Welles-Nyström B, Vorontsov I, et al. Early lactation performance in primiparous and multiparous women in relation to different maternity home practices. A randomised trial in St. Petersburg. Int Breastfeed J. 2007;2:9.

28. Widstrom AM, Ransjo-Arvidson AB, Christensson $\mathrm{K}$, Matthiesen AS, Winberg J, Uvnas-Moberg K. Gastric suction in healthy newborn infants. Effects on circulation and developing feeding behaviour. Acta Paediatr Scand. 1987;76:566-72.

29. Fairbank L, O'Meara S, Renfrew M, Woolridge M, Sowden A, Lister-Sharp D. A systematic review to evaluate the effectiveness of interventions to promote the initiation of breastfeeding. Health Technol Assess. 2000;4(25):1-171.

30. Pérez-Escamilla R, Pollitt E, Lönnerdal B, Dewey KG. Infant feeding policies in maternity wards and their effect on breastfeeding success: an analytical overview. Am J Public Health. 1994;84(1):89-97.

31. Christensson K, Siles C, Moreno L, Belaustequi A, de la Fuente P, Lagercrantz H, et al. Temperature, metabolic adaptation and crying in healthy, full-term newborns cared for skin-to-skin or in a cot. Acta Paediatr Scand. 1992;81:488-93.

32. Bystrova K, Widstrom AM, Matthiesen AS, RansjoArvidson AB, Welles-Nyström B, Wassberg C, et al. Skin-to-skin contact may reduce negative consequences of "the stress of being born": a study on temperature in newborn infants, subjected to different ward routines in St. Petersburg. Acta Paediatr. 2003;92:320-6.

33. Christensson K, Cabrera T, Christensson E, UvnasMoberg K, Winberg J. Separation distress call in the human neonate in the absence of maternal body contact. Acta Paediatr. 1995;84(5):468-73.

34. Tan KL. Knowledge, attitude and practice of breastfeeding in Klang, Malaysia. Int Med $\mathbf{J}$ 2009;8:17-21.

35. Hajian-Tilaki KO. Factors associated with the pattern of breastfeeding in the north of Iran. Ann Hum Biol. 2005;32:702-13.

36. Agho KE, Dibley MJ, Odiase JI, Ogbonmwan SM. Determinants of exclusive breastfeeding in Nigeria. BMC Pregn Childbirth. 2011;11:2.

37. Federal Office of Statistics (FOS) (Nigeria) and IRD/Macro International Inc. Nigeria demographic and health survey 2003. In: FOS, eds. FOS Survey. Columbia, Maryland: Federal Office of Statistics and IRD/Macro International Inc; 2004.

38. Parkinson KN, Drewett, RF. Feeding behaviour in the weaning period. J Child Psycho Psychiatry. 2001;42:971-8.

39. Bolling K, Grant C, Hamlyn B, Thornton A. UK infant feeding survey 2005, 2007. Available at: http://www.ic.nhs.uk/pubs/ifs Accessed 5 March 2012.

40. Hornell A, Hofvander Y, Kylberg E. Introduction of solids and formula to breastfed infants: a longitudinal prospective study in Uppsala, Sweden. Acta Paediatr. 2001;90:477-82.

41. Wright CM, Parkinson KN, Drewett RF. Why are babies weaned early? Data from a prospective population based cohort study. Arch Dis Child. 2004;89:813-6.

42. Schiess S, Grote V, Scaglioni S, Luque V, Martin F, Stolarczyk A, et al. European childhood obesity project. Introduction of complementary feeding in 5 European countries. J Paediatr Gastroenterol Nutr. 2009;49:1-8.

43. Armentia A, Banuelos C, Arranz ML, Del Villar V, Martín-Santos JM, Gil FJ, et al. Early introduction of 
cereals into children's diets as a risk-factor for grass pollen asthma. Clin Exp Allergy. 2001;31:1250-5.

44. Fergusson DM, Horwood LJ, Shannon FT. Early solid feeding and recurrent childhood eczema: a 10year longitudinal study. Pediatrics. 1990;86:541-6.

45. Kajosaari M. Atopy prophylaxis in high-risk infants. Adv Exp Med Biol. 1991;310:453-8.

46. Forsyth JS, Ogston SA, Clark A, Florey CD, Howie PW. Relation between early introduction of solid food to infants and their weight and illnesses during the first two years of life. BMJ. 1993;306:1572-6.

47. Popkin BM, Adair L, Akin JS, Black R, Briscoe J, Flieger W. Breastfeeding and diarrheal morbidity. Pediatrics. 1990;86:874-82.

48. Wilson AC, Forsyth JS, Greene SA, Irvine L, Hau C, Howie PW. Relation of infant diet to childhood health: seven year follow up of cohort of children in Dundee infant feeding study. BMJ. 1998;316:21-5.

49. Perez-Escamilla R. Update on the breastfeeding situation in Africa. Nutr Res. 1993;13:597-609.

50. World Health Organization (WHO). Infant and young child nutrition. In: WHO, ed. Fifty-fourth World Health Assembly no. 54•2. Geneva: WHO; 2001: 1-4.

51. Ross L. Weaning practices. J Nurse-Midwif. 1981;26:9-14.

52. Khakoo, GA, Lack G. Introduction of solids to the infant diet. Arch Dis Child. 2004;89:295.

53. Ward Platt MP. Demand weaning: infants' answer to professionals' dilemmas. Arch Dis Child. 2009;94:79-80.

54. Condon L, Ingram J, Hamid N, Hussein A. Cultural influences on breastfeeding and weaning. Community Practition. 2003;76(9):344-9.

55. Lee H. Racial/ethnic differences in breastfeeding initiation and duration among low-income inner-city mothers. Soc Sci Quarter. 2009;90(5):1251-71.

56. Flacking R, Nyqvist KH, Ewald U. Effects of socioeconomic status on breastfeeding duration in mothers of preterm and term infants. Eur J Public Health. 2007;17(6):579-84.

57. Avery M, Duckett L, Dodgson J, Savik K, Henly SJ. Factors associated with very early weaning among primiparas intending to breastfeed. Matern Child Health J. 1998;2(3):167-79.

58. Rice S, Coombs D, Fish L, Leeper J. Breast feeding and contraception in Peru. J Health Popul Nutr. 2002;20(1):51-8.

59. Huffman SL, Chowdhury AKMA, Chakraborty J, Simpson NK. Breast feeding patterns in rural Bangladesh. Am J Clin Nutr. 1980;33:144-54.

60. Jakobsen MS, Sodemann M, Molbak K, Aaby P. Reason for terminating breastfeeding and the length of breastfeeding. Int J Epidemiol. 1996;25:115-21.

61. Simondon KB, Costes R, Delaunay V, Diallo A, Simondon F. Children's height, health and appetite influence mothers' weaning decisions in rural Senegal. Int J Epidemiol. 2001;30:476-81.
62. Scott JA, Binns CW. Factors associated with the initiation and duration of breastfeeding: a review of the literature. Breastfeed Rev. 1999;7(1):5-16.

63. Williams PL, Innis SM, Vogel AMP, Stephen LJ. Factors influencing infant feeding practices of mothers in Vancouver. Can J Public Health. 1999;117(90):114-9.

64. Northstone K, Emmett P, Nethersole F. ALSPAC study team. Avon longitudinal study of pregnancy and childhood. The effect of age of introduction to lumpy solids on foods eaten and reported feeding difficulties at 6 and 15 months. J Hum Nutr Diet. 2001;14:43-54.

65. Tarrant R, Younger K, Sheridan-Pereira M, White M, Kearney J. Factors associated with weaning practices in term infants: a prospective observational study in Ireland. Br J Nutr. 2010;104(10):1544-54.

66. Wright C, Birks E. Risk factors for failure to thrive: a population-based survey. Child Care Health Dev. 2000;26:5-16.

67. Eregie CO. Observations on water supplementation in breastfed infants. West Afr $J$ Med. 2001;20(4):210-2.

68. Kakute PN, Ngum J, Mitchell P, Kroll KA, Forgwei GW, Ngwang LK, et al. Cultural barriers to exclusive breastfeeding by mothers in a rural area of Cameroon, Africa. J Midwif Womens Health. 2005;50(4):324-8.

69. Davies-Adetugbo AA. Sociocultural factors and the promotion of exclusive breastfeeding in rural Yoruba communities of Osun State, Nigeria. Soc Sci Med. 1997;45(1):113-25.

70. Abiona TC, Onayade AA, Ijadunola KT, Obiajunwa PO, Aina OI, Thairu LN. Acceptability, feasibility and affordability of infant feeding options for HIVinfected women: a qualitative study in south-west Nigeria. Matern Child Nutr. 2006;2:135-44.

71. Scariati PD, Grummer-Strawn LM, Fein SB. Water supplementation of infants in the first month of life. Arch Paediatr Adolesc Med. 1997;151(8):830-2.

72. Nath DC, Goswami G. Determinants of breastfeeding patterns in an urban society of India. Hum Biol. 1997;69:557-73.

73. Dubois L, Girard M. Social inequalities in infant feeding during the first year of life. The longitudinal study of child development in Quebec (LSCDQ 1998-2002). Public Health Nutr. 2003;6:773-83.

74. Di Napoli A, Di Lallo D, Pezzotti P, Forastiere F, Porta D. Effects of parental smoking and level of education on initiation and duration of breastfeeding. Acta Paediatr. 2006;95:678-85.

75. Ong G, Yap M, Foo LL, Tai BC. Impact of working status on breastfeeding in Singapore: evidence from the national breastfeeding survey 2001. Eur J Public Health. 2005;15(4):424-30.

76. Aslam S, Sultan M, Akram F. Exclusive breast feeding; duration at Northern areas of Pakistan a hospital based study. Professional Med J. 2010;17(2):286-90. 
77. Giashuddin MS, Kabir M. Breastfeeding duration in Bangladesh and factors associated with it. Indian $\mathrm{J}$ Community Med. 2003;28:34-8.

78. Bautista LE. Factors associated with the initiation of breast feeding by women in the Dominican Republic. Revista Panamericana de Salud Publica. 1997;1:2007.

79. Scott JA, Binns CW, Oddy WH, Graham KI. Predictors of breastfeeding duration: evidence from a cohort study. Pediatrics. 2006;117:e646-55.
80. Giashuddin MS, Kabir M. Duration of breastfeeding in Bangladesh. Indian J Med Res. 2004;119:267-72.

DOI: $10.5455 / 2320-1770 . i j \operatorname{cog} 20141218$

Cite this article as: Mbada CE, Olowokere AE, Faronbi JO, Faremi FA, Oginni MO, OyinlolaAromolaran FC, Odeyemi ES, Augustine OA. Breastfeeding profile and practice of Nigerian mothers: a cross-sectional survey. Int J Reprod Contracept Obstet Gynecol 2014;3:969-76. 